\title{
The use of Monte Carlo simulation to predict vancomycin dosage for methicillin-resistant Staphylococcus aureus in Thai patients of various ages and with varying degrees of renal function
}

\author{
Krairerk Pitaksontayothin', Wichai Santimaleeworagun ${ }^{1,2, *}$, Manat Pongchaidecha1,", \\ Jantana Houngsaitong ${ }^{3}$, Panuwit Srisena ${ }^{4}$
}

\begin{abstract}
Background: To our knowledge, no study reported so far has investigated appropriate vancomycin dosing, which is important for treatment of methicillin-resistant Staphylococcus aureus (MRSA) infection in Thai patients of various ages and with varying degrees of renal function.

Objectives: To predict vancomycin dosing for MRSA in Thai patients of various ages and with varying degrees of renal functions.

Methods: Monte Carlo simulation and minimal inhibitory concentration (MIC) distribution of MRSA from a hospital in Thailand were used to predict the area under the curve in $24 \mathrm{~h} / \mathrm{MIC}>400$ and trough concentration $\left(C_{\text {trough }}\right)<20 \mathrm{mg} / \mathrm{L}$ of 9 vancomycin dosage regimens for Thai patients stratified by age and renal function.

Results: Vancomycin dosing at least $2.5 \mathrm{~g}$ per day can attain cumulative fraction of response (CFR) of $\geq 90 \%$ in every age group. Vancomycin dosage achieving CFR of $\geq 90 \%$ for simulated patients with creatinine clearance $\left(\mathrm{CL}_{\mathrm{cr}}\right)$ was calculated using the Cockcroft-Gault equation. Appropriate vancomycin doses for Thai patients infected with MRSA with $\mathrm{CL}_{\text {cr }}$ of $<40,40-60,>60-80$, and $>80 \mathrm{~mL} / \mathrm{min}$ were $1.5 \mathrm{~g}$ every $24 \mathrm{~h}, 1.25 \mathrm{~g}$ every $12 \mathrm{~h}, 1 \mathrm{~g}$ every $8 \mathrm{~h}$, and $1.75 \mathrm{~g}$ every $12 \mathrm{~h}$, respectively. However, more than a half of patients simulated using these regimens have a vancomycin $C_{\text {trough }}$ of $>20 \mathrm{mg} / \mathrm{L}$.

Conclusions: Although vancomycin doses attaining a CFR of $\geq 90 \%$ can treat MRSA infection effectively, the regimens may cause kidney injury. The regimens have a probability of target attainment of $100 \%$, and most patients can attain $C_{\text {trough }}$ of $<20 \mathrm{mg} / \mathrm{L}$.
\end{abstract}

Keywords: Monte Carlo simulation, MRSA, Thai patients, vancomycin dosing

*Correspondence to: Wichai Santimaleeworagun, Department of Pharmacy, Faculty of Pharmacy, Silpakorn University, Nakhon Pathom 73000, Thailand; Antibiotic Optimization and Patient Care Project by Pharmaceutical Initiative for Resistant Bacteria and Infectious Diseases Working Group (PIRBIG), Faculty of Pharmacy, Silpakorn University, Nakhon Pathom 7300, Thailand, e-mail: santimaleeworag_w@su.ac.th;

Manat Pongchaidecha, Department of Pharmacy, Faculty of Pharmacy, Silpakorn University, Nakhon Pathom 73000, Thailand,

e-mail: pongchaidecha_m@su.ac.th

'Department of Pharmacy, Faculty of Pharmacy, Silpakorn University, Nakhon Pathom 73000, Thailand

${ }^{2}$ Antibiotic Optimization and Patient Care Project by Pharmaceutical Initiative for Resistant Bacteria and Infectious Diseases Working Group

(PIRBIG), Faculty of Pharmacy, Silpakorn University, Nakhon Pathom 7300, Thailand

${ }^{3}$ Department of Pharmacy, Faculty of Pharmacy, Mahidol University, Bangkok 10400, Thailand

${ }^{4}$ Pharmacy Department, Chaoprayayomraj Hospital, Suphan Buri 72000, Thailand

(c) (1) () $\odot 2017$ Krairerk Pitaksontayothin, Wichai Santimaleeworagun, Manat Pongchaidecha, Jantana Houngsaitong, Panuwit Srisena

This Work is licensed under Creative Common License 
Vancomycin plays an important role in treating methicillinresistant Staphylococcus aureus (MRSA) infection in Thai patients. Although some evidence suggests appropriate vancomycin dosing for patients infected with MRSA, vancomycin dosing may be affected by various conditions, such as race [1, 2], age [3], body weight [4], and renal function [5]. Therefore, vancomycin dosing calculated for patients in other countries may not be appropriate to use for Thai patients. Purwonugroho et al. conducted a study to provide specific vancomycin population pharmacokinetics in Thai patients [6]. The study illustrated that creatinine clearance $\left(\mathrm{CL}_{\mathrm{cr}}\right)$ calculated by the Cockcroft-Gault equation and age were covariates of vancomycin clearance $\left(\mathrm{CL}_{v}\right)$ and volume of the central compartment $\left(V_{c}\right)$, respectively. Thus, suitable vancomycin dosage could vary depending on $\mathrm{CL}_{\mathrm{cr}}$ and age. In addition, MRSA susceptibility data to vancomycin is a crucial factor for evaluating proper vancomycin dosing. Canut et al. determined suitable vancomycin dosages for European patients with MRSA infection [7]. The study revealed that Belgian patients can use vancomycin $1 \mathrm{~g}$ every $12 \mathrm{~h}$ as adequate dosing, but Spanish patients have to use vancomycin at least $1 \mathrm{~g}$ every $8 \mathrm{~h}$ because they are infected with MRSA with lower susceptibility to vancomycin.

Monte Carlo simulation is useful to predict a suitable vancomycin dosing regimen because it can provide the outcome without using data from actual patients. Although previous studies have already used simulations to determine appropriate vancomycin dosing [8-10], to our knowledge, no published study has investigated appropriate vancomycin dosing for Thai patients of various ages and with varying degrees of renal function. Therefore, the aim of the present study was to predict appropriate vancomycin dosing regimens for Thai patients of various ages and with varying degrees of renal function.

\section{Materials and methods}

\section{Susceptibility data for MRSA isolates}

After the approval from institutional review boards of Silpakorn University (approval No. 1/2558) and Chaoprayayomraj Hospital (approval No. YM 014/2558), 105 unduplicated MRSA isolates from Chaoprayayomraj Hospital, Thailand, were accumulated during 2014. The MRSA vancomycin susceptibility data were determined using an Epsilometer test or E-test (M.I.C.E; Thermo Fisher Scientific) in accordance with CLSI 2014.

\section{Pharmacokinetic parameters of vancomycin}

A simulation was conducted using previously published population pharmacokinetic models derived from 212 Thai patients with 319 vancomycin serum concentration data to develop pharmacokinetic parameters. The 2-compartment model was the best structural model to fit the population data. Pharmacokinetic parameters were vancomycin clearance $\left(\mathrm{CL}_{\mathrm{v}}\right)(\mathrm{L} / \mathrm{h})=0.044 \times \mathrm{CL}_{\mathrm{cr}}(\mathrm{mL} / \mathrm{min})$, the central volume of distribution $\left(V_{\mathrm{c}}\right)(\mathrm{L})=0.542 \times$ age (years), intercompartment clearance $(Q)=6.95 \mathrm{~L} / \mathrm{h}$, and volume of peripheral compartment $\left(V_{\mathrm{p}}\right)=44.2 \mathrm{~L}$ [6].

\section{Pharmacodynamic index}

The ratio of the 24-h area under the concentration-time curve $\left(\mathrm{AUC}_{24}\right)$ and minimum inhibitory concentration (MIC) $\geq 400$ was the marker of a good outcome of MRSA treatment with vancomycin [11]. Thus, $\mathrm{AUC}_{24} / \mathrm{MIC} \geq 400$ was used as a target value of pharmacodynamic index.

\section{Monte Carlo simulation}

Monte Carlo simulation is a stochastic simulation method that randomly selects a parameter value from a known distribution. The process is repeated many times (usually 10,000) to generate pharmacokinetic parameters [12]. The generated pharmacokinetic parameters of each simulated patient are incorporated with the structural pharmacokinetics model, MIC distribution, and target value of the pharmacodynamic index to predict the efficacy of antibiotic dosing [13].

A total of 10,000 simulated patients were generated by Monte Carlo simulation using Oracle Crystal Ball software (Oracle Crystal Ball Faculty Classroom Edition) for each vancomycin dosing including $0.75,1$, and $1.5 \mathrm{~g}$ every $24 \mathrm{~h}$; $1,1.25,1.75$, and $2 \mathrm{~g}$ every $12 \mathrm{~h}$; and $1 \mathrm{~g}$ every $8 \mathrm{~h}$. The age and $\mathrm{CL}_{\mathrm{cr}}$ of simulated patients were specified ranging from 20 to 80 years and 20 to $100 \mathrm{~mL} / \mathrm{min}$, respectively. The mean (standard deviation) values of age and $\mathrm{CL}_{\mathrm{cr}}$ were assumed to be $50(30)$ years and $60(40) \mathrm{mL} / \mathrm{min}$, respectively. $V_{\mathrm{c}}$ and $\mathrm{CL}_{v}$ were assumed to be lognormal distributions. $\mathrm{AUC}_{24}$ at steady state was computed using the trapezoidal rule. The 10,000 simulated patients who were each administrated vancomycin dosage were grouped by age and renal function. The age group of patients was defined as $<40,40-60$, and $>60$ years. In addition, the $\mathrm{CL}_{\text {cr }}$ group of patients was defined as $<40,40-60,>60-80$, and $>80 \mathrm{~mL} / \mathrm{min}$. After the 
simulated patients were grouped, the probability of target attainment (PTA) of each MIC was computed, and then, the cumulative fraction of response (CFR) for each vancomycin dosing administered in each patient group was calculated as follows:

$$
\mathrm{CFR}=\sum_{i=1}^{n} \mathrm{PTA}_{i} \times F_{i}
$$

where the subscript $i$ indicates the MIC group classified from lowest to highest MIC value of MRSA isolates, $\mathrm{PTA}_{i}$ stands for the PTA for $\mathrm{AUC}_{24} / \mathrm{MIC} \geq 400$ of each MIC, and $F$ is the ratio of the MRSA isolates at each MIC.

To evaluate the risk of renal toxicity, this study assessed the probability of attaining a trough concentration $\left(C_{\text {trough }}\right)$ of vancomycin of $\leq 20 \mathrm{mg} / \mathrm{L},>20-35 \mathrm{mg} / \mathrm{L}$, and $>35 \mathrm{mg} / \mathrm{L}$ in each group of patients who received vancomycin.

\section{Results}

The distribution of simulated patients in various age groups, including <40, 40-60, and >60 years, was approximately $45 \%, 35 \%$, and $20 \%$, respectively, whereas that in various renal function groups, including <40, 40-60, >60-80, and $>80 \mathrm{~mL} / \mathrm{min}$, was approximately $36 \%, 32 \%, 20 \%$, and $12 \%$, respectively (data not shown). Sources of specimens of 105 non-duplicated MRSA isolates and MIC distribution are given in Table 1. The PTA of each MIC according to patient age and renal function is listed in Tables $\mathbf{2}$ and $\mathbf{3}$, respectively. Figure 1 illustrates that vancomycin dosing at least $2.5 \mathrm{~g}$ per day can attain CFR $\geq 90 \%$ in every age group. In addition, for simulated patients with $\mathrm{CL}_{\mathrm{cr}}<40$, $40-60,>60-80$, and $>80 \mathrm{~mL} / \mathrm{min}$, vancomycin dosages that can achieve CFR $\geq 90 \%$ are $1.5,2.5,3$, and 3.5 g per day, respectively, as shown in Figure 2. More than a half of simulated patients using these regimens attained a $C_{\text {trough }}$ of $>20 \mathrm{mg} / \mathrm{L}$.

Table 1. The numbers of methicillin-resistant Staphylococcus aureus (MRSA) clinical isolates according to source of specimens and minimal inhibitory concentration (MIC) distribution $(n=105)$

\begin{tabular}{|c|c|c|c|}
\hline \multirow{2}{*}{ MIC (mg/L) } & \multicolumn{2}{|c|}{ Source of specimens } & \multirow{2}{*}{ Total (\%) } \\
\hline & Sputum & Blood & \\
\hline 0.5 & 5 & 0 & $5(4.8)$ \\
\hline 1 & 56 & 1 & $57(54.3)$ \\
\hline 2 & 41 & 1 & $42(40)$ \\
\hline 4 & 1 & 0 & $1(1)$ \\
\hline
\end{tabular}

\section{Discussion}

Both PTA and CFR are outcomes of simulation applied to evaluate effectiveness of each vancomycin dosing regimen. The higher the trough concentration of vancomycin, the higher the risk of nephrotoxicity $[14,15]$. Therefore, to evaluate the safety of vancomycin administration, percentage of achieving trough concentration for each vancomycin dosage should be taken into consideration.

Simulated patients in the present study presented with vancomycin dosages based on $\mathrm{CL}_{\mathrm{cr}}$ and age. It is not surprising that $\mathrm{CL}_{\mathrm{cr}}$ is a significant factor for $\mathrm{CL}_{\mathrm{v}}$ [6], but that an increa$\operatorname{sing} V_{\mathrm{c}}$ is related to an increasing age.

We found that a vancomycin dose of $1.5 \mathrm{~g}$ per day can attain CFR $\geq 90 \%$ in all age groups. Variation in age may rarely influence the change in $\mathrm{AUC}_{24}$. However, the result is inconsistent with findings by Revilla et al. [3] who compared the estimated CFR between critically ill patients aged $>65$ years and younger patients with no severe renal impairment $\left(\mathrm{CL}_{\mathrm{cr}}>60 \mathrm{~mL} / \mathrm{min}\right)$.

Table 2. The probability of target attainment (PTA) of an area under the curve $(A \cup C) /$ minimal inhibitory concentration $(\mathrm{MIC})>400$ at each MIC according to age of patients

\begin{tabular}{|c|c|c|c|c|c|}
\hline \multirow{2}{*}{$\begin{array}{l}\text { Age } \\
\text { (years) }\end{array}$} & \multirow{2}{*}{$\begin{array}{l}\text { Vancomycin } \\
\text { dosing }\end{array}$} & \multicolumn{4}{|c|}{ PTA of each MIC (\%) } \\
\hline & & 0.5 & 1 & 2 & 4 \\
\hline \multirow[t]{8}{*}{$<40$} & $0.75 \mathrm{~g}$ every $24 \mathrm{~h}$ & 92.3 & 42.0 & 1.9 & 0.0 \\
\hline & $1 \mathrm{~g}$ every $24 \mathrm{~h}$ & 100 & 64.6 & 13.8 & 0.0 \\
\hline & $1.5 \mathrm{~g}$ every $24 \mathrm{~h}$ & 100 & 92.4 & 39.9 & 1.5 \\
\hline & 1 g every $12 \mathrm{~h}$ & 100 & 100 & 62.3 & 14.1 \\
\hline & $1.25 \mathrm{~g}$ every $12 \mathrm{~h}$ & 100 & 100 & 80.2 & 27.5 \\
\hline & $1 \mathrm{~g}$ every $8 \mathrm{~h}$ & 100 & 100 & 92.3 & 41.2 \\
\hline & 1.75 g every $12 \mathrm{~h}$ & 100 & 100 & 99.6 & 53.3 \\
\hline & 2 g every $12 \mathrm{~h}$ & 100 & 100 & 100 & 63.9 \\
\hline \multirow[t]{8}{*}{$40-60$} & 0.75 g every $24 \mathrm{~h}$ & 91.9 & 41.8 & 1.8 & 0.0 \\
\hline & $1 \mathrm{~g}$ every $24 \mathrm{~h}$ & 100 & 60.8 & 13.3 & 0.0 \\
\hline & $1.5 \mathrm{~g}$ every $24 \mathrm{~h}$ & 100 & 92.7 & 41.5 & 1.6 \\
\hline & $1 \mathrm{~g}$ every $12 \mathrm{~h}$ & 100 & 100 & 63.5 & 13.9 \\
\hline & $1.25 \mathrm{~g}$ every $12 \mathrm{~h}$ & 100 & 100 & 80.2 & 26.8 \\
\hline & $1 \mathrm{~g}$ every $8 \mathrm{~h}$ & 100 & 100 & 92.6 & 41.1 \\
\hline & $1.75 \mathrm{~g}$ every $12 \mathrm{~h}$ & 100 & 100 & 99.7 & 54.1 \\
\hline & $2 \mathrm{~g}$ every $12 \mathrm{~h}$ & 100 & 100 & 100 & 65.5 \\
\hline \multirow[t]{8}{*}{$>60$} & $0.75 \mathrm{~g}$ every $24 \mathrm{~h}$ & 91.3 & 39.9 & 1.2 & 0.0 \\
\hline & $1 \mathrm{~g}$ every $24 \mathrm{~h}$ & 100 & 62.8 & 13.3 & 0.0 \\
\hline & $1.5 \mathrm{~g}$ every $24 \mathrm{~h}$ & 100 & 93.2 & 41.6 & 1.3 \\
\hline & $1 \mathrm{~g}$ every $12 \mathrm{~h}$ & 100 & 100 & 62.3 & 14.2 \\
\hline & $1.25 \mathrm{~g}$ every $12 \mathrm{~h}$ & 100 & 100 & 79.6 & 28.1 \\
\hline & $1 \mathrm{~g}$ every $8 \mathrm{~h}$ & 100 & 100 & 92.3 & 39.8 \\
\hline & $1.75 \mathrm{~g}$ every $12 \mathrm{~h}$ & 100 & 100 & 99.7 & 52.0 \\
\hline & $2 \mathrm{~g}$ every $12 \mathrm{~h}$ & 100 & 100 & 100 & 64.1 \\
\hline
\end{tabular}


Table 3. The probability of target attainment (PTA) of an area under the curve (AUC)/minimal inhibitory concentration (MIC) $>400$ at each MIC according to renal function of patients

\begin{tabular}{|c|c|c|c|c|c|}
\hline \multirow{2}{*}{$\begin{array}{l}\mathrm{CL}_{\mathrm{cr}} \\
(\mathrm{mL} / \\
\mathrm{min})\end{array}$} & \multirow{2}{*}{$\begin{array}{l}\text { Vancomycin } \\
\text { dosing }\end{array}$} & \multicolumn{4}{|c|}{ PTA of each MIC (\%) } \\
\hline & & 0.5 & 1 & 2 & 4 \\
\hline \multirow[t]{8}{*}{$<40$} & $0.75 \mathrm{~g}$ every $24 \mathrm{~h}$ & 100 & 100 & 4.7 & 0.0 \\
\hline & $1 \mathrm{~g}$ every $24 \mathrm{~h}$ & 100 & 100 & 38.7 & 0.0 \\
\hline & $1.5 \mathrm{~g}$ every $24 \mathrm{~h}$ & 100 & 100 & 100 & 4.1 \\
\hline & $1 \mathrm{~g}$ every $12 \mathrm{~h}$ & 100 & 100 & 100 & 40.0 \\
\hline & 1.25 g every $12 \mathrm{~h}$ & 100 & 100 & 100 & 77.3 \\
\hline & $1 \mathrm{~g}$ every $8 \mathrm{~h}$ & 100 & 100 & 100 & 100 \\
\hline & $1.75 \mathrm{~g}$ every $12 \mathrm{~h}$ & 100 & 100 & 100 & 100 \\
\hline & $2 \mathrm{~g}$ every $12 \mathrm{~h}$ & 100 & 100 & 100 & 100 \\
\hline \multirow[t]{8}{*}{$40-60$} & 0.75 g every $24 \mathrm{~h}$ & 100 & 14.7 & 0.0 & 0.0 \\
\hline & $1 \mathrm{~g}$ every $24 \mathrm{~h}$ & 100 & 86.3 & 0.0 & 0.0 \\
\hline & 1.5 g every $24 \mathrm{~h}$ & 100 & 100 & 14.4 & 0.0 \\
\hline & $1 \mathrm{~g}$ every $12 \mathrm{~h}$ & 100 & 100 & 86.3 & 0.0 \\
\hline & 1.25 g every $12 \mathrm{~h}$ & 100 & 100 & 100 & 0.0 \\
\hline & $1 \mathrm{~g}$ every $8 \mathrm{~h}$ & 100 & 100 & 100 & 14.6 \\
\hline & $1.75 \mathrm{~g}$ every $12 \mathrm{~h}$ & 100 & 100 & 100 & 53.1 \\
\hline & $2 \mathrm{~g}$ every $12 \mathrm{~h}$ & 100 & 100 & 100 & 87.0 \\
\hline \multirow[t]{8}{*}{$>60-80$} & $0.75 \mathrm{~g}$ every $24 \mathrm{~h}$ & 100 & 0.0 & 0.0 & 0.0 \\
\hline & $1 \mathrm{~g}$ every $24 \mathrm{~h}$ & 100 & 0.0 & 0.0 & 0.0 \\
\hline & $1.5 \mathrm{~g}$ every $24 \mathrm{~h}$ & 100 & 100 & 0.0 & 0.0 \\
\hline & $1 \mathrm{~g}$ every $12 \mathrm{~h}$ & 100 & 100 & 0.0 & 0.0 \\
\hline & $1.25 \mathrm{~g}$ every $12 \mathrm{~h}$ & 100 & 100 & 59.6 & 0.0 \\
\hline & $1 \mathrm{~g}$ every $8 \mathrm{~h}$ & 100 & 100 & 100 & 0.0 \\
\hline & $1.75 \mathrm{~g}$ every $12 \mathrm{~h}$ & 100 & 100 & 100 & 0.0 \\
\hline & $2 \mathrm{~g}$ every $12 \mathrm{~h}$ & 100 & 100 & 100 & 0.0 \\
\hline \multirow[t]{8}{*}{$>80$} & $0.75 \mathrm{~g}$ every $24 \mathrm{~h}$ & 31.9 & 0.0 & 0.0 & 0.0 \\
\hline & $1 \mathrm{~g}$ every $24 \mathrm{~h}$ & 100.0 & 0.0 & 0.0 & 0.0 \\
\hline & $1.5 \mathrm{~g}$ every $24 \mathrm{~h}$ & 100.0 & 33.1 & 0.0 & 0.0 \\
\hline & $1 \mathrm{~g}$ every $12 \mathrm{~h}$ & 100.0 & 100 & 0.0 & 0.0 \\
\hline & $1.25 \mathrm{~g}$ every $12 \mathrm{~h}$ & 100.0 & 100 & 0.0 & 0.0 \\
\hline & $1 \mathrm{~g}$ every $8 \mathrm{~h}$ & 100.0 & 100 & 32.5 & 0.0 \\
\hline & $1.75 \mathrm{~g}$ every $12 \mathrm{~h}$ & 100.0 & 100 & 97.2 & 0.0 \\
\hline & $2 \mathrm{~g}$ every $12 \mathrm{~h}$ & 100.0 & 100 & 100 & 0.0 \\
\hline
\end{tabular}

$\mathrm{CL}_{\mathrm{cr}^{\prime}}$ creatinine clearance calculated using the Cockcroft-Gault equation

Both groups were given vancomycin at $1 \mathrm{~g}$ every $12 \mathrm{~h}$. They found that CFR was inversely proportional to age. Their estimated CFR of critically ill patients aged $>65$ years was $65 \%$ but was $30 \%$ in younger patients. The present study found that a vancomycin dosage of $2 \mathrm{~g}$ daily, a usual dose for a patient with normal renal function (estimated from the recommended dose of 15-20 mg/kg every $12 \mathrm{~h}$ ) [16], reached the CFR in only $64.3 \%$ of patients with $\mathrm{CL}_{\mathrm{cr}}>80 \mathrm{~mL} / \mathrm{min}$. However, this was not surprising because the usual dose suggested by clinical guidelines is recommended for patients infected with
MRSA with an MIC of $\leq 1 \mathrm{mg} / \mathrm{L}$. By contrast, the frequency of MRSA with an MIC of $2 \mathrm{mg} / \mathrm{L}$ in the present study was high $(40 \%)$. Accordingly, Thai patients need a higher vancomycin dose for empirical treatment of MRSA infection. Vancomycin is excreted primarily by kidney [17]. Patients with good kidney function need higher vancomycin dosing than patients with poor kidney function to successfully treat MRSA infection. The present study showed that vancomycin dosing of at least $1.5,2.5,3$, and $3.5 \mathrm{~g}$ per day could achieve CFR of $\geq 90 \%$ in patients with $\mathrm{CL}_{\mathrm{cr}}$ of $<40,40-60,>60-80,>80 \mathrm{~mL} / \mathrm{min}$, respectively. Thus, besides the data for vancomycin susceptibility of MRSA isolates, patient renal function has a strong effect on CFR for each vancomycin dosing.

Trough concentration of vancomycin of $>20 \mathrm{mg} / \mathrm{L}$ is related to undesirable nephrotoxicity. A higher trough level is associated with a higher incidence of renal toxicity [18]. Therefore, trough concentration of vancomycin will need to be considered. As shown in Figures 1 and 2, as a result of high MIC, high vancomycin doses were necessary to attain a CFR of $\geq 90 \%$. Therefore, the patients using these regimens will have a high possibility of having a serum trough concentration of $>20 \mathrm{mg} / \mathrm{L}$ and vancomycin-induced kidney injury may occur in them. Consequently, patients using these regimens should be monitored closely for renal function, especially patients receiving concomitant nephrotoxic agents [19]. Nevertheless, we note that vancomycin can be used effectively and safely in patients infected with MRSA with a vancomycin MIC of $\leq 1 \mathrm{mg} / \mathrm{L}$. Vancomycin doses of $0.75,1.5$, 1.5 , and $2 \mathrm{~g}$ daily for patients with a $\mathrm{CL}_{\mathrm{cr}}$ of $<40,40-60,>60-80$, and $>80 \mathrm{~mL} / \mathrm{min}$, respectively, should be given to patients infected with MRSA with a vancomycin MIC $\leq 1 \mathrm{mg} / \mathrm{L}$ because these regimens can attain a PTA of $100 \%$ and the majority of patients can attain a $C_{\text {trough }}$ of $\leq 20 \mathrm{mg} / \mathrm{L}$. The results are similar to the recommendation from clinical guidelines suggesting that the use of vancomycin should be limited to patients with MRSA infection with a vancomycin MIC of $\leq 1 \mathrm{mg} / \mathrm{L}$ [20].

The present study has some limitations. First, vancomycin susceptibility data against MRSA were accumulated from a regional hospital in Thailand. Thus, the sensitivity profile of MRSA to vancomycin in the present study may not be applicable for the prediction of appropriate vancomycin doses for all Thai patients. Further studies collecting MRSA sensitivity data from several types of hospitals in various regions are required to predict the vancomycin dosage more widely. Second, despite that we could find therapeutic vancomycin doses for patients with a $\mathrm{CL}_{\mathrm{cr}}$ of $<40 \mathrm{~mL} / \mathrm{min}$, vancomycin concentration in these patients may take some time to reach a steady state. The initial low concentration of vancomycin may increase the rate of mortality, and MRSA resistance to vancomycin may develop [21,22]. Thus, a suitable loading dose may be necessary to reach a therapeutic concentration promptly. 

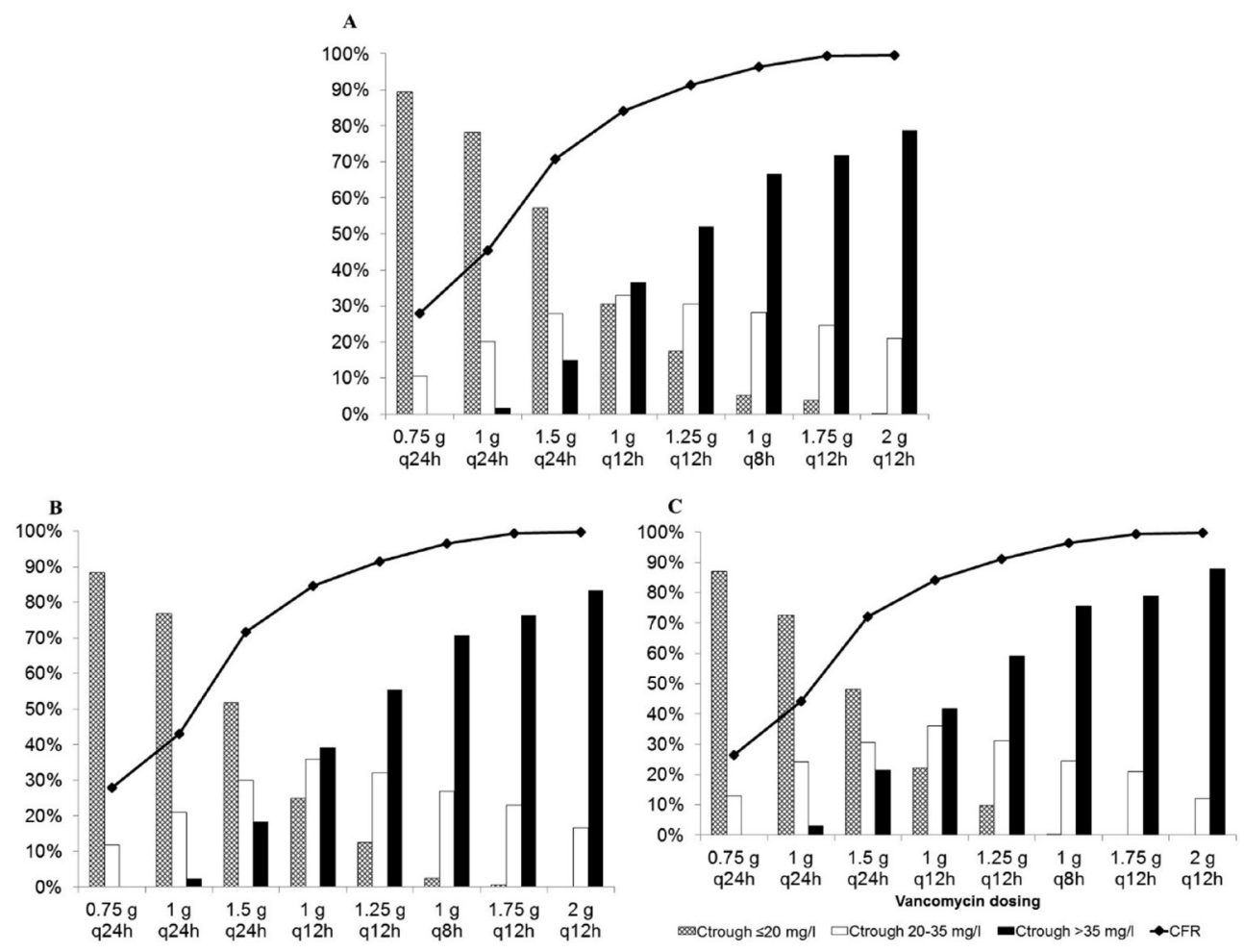

Figure 1. The cumulative fraction of response (CFR) achieving an area under the curve (AUC)/minimal inhibitory concentration (MIC) $>400$ and the percentage of trough concentration $\left(C_{\text {trough }}\right)$ of vancomycin at steady state for each dosing regimen in simulated patients of various ages. (A) $<40$ years, (B) $40-60$ years, and (C) $>60$ years. $q=$ quaque or every; $I=$ liter
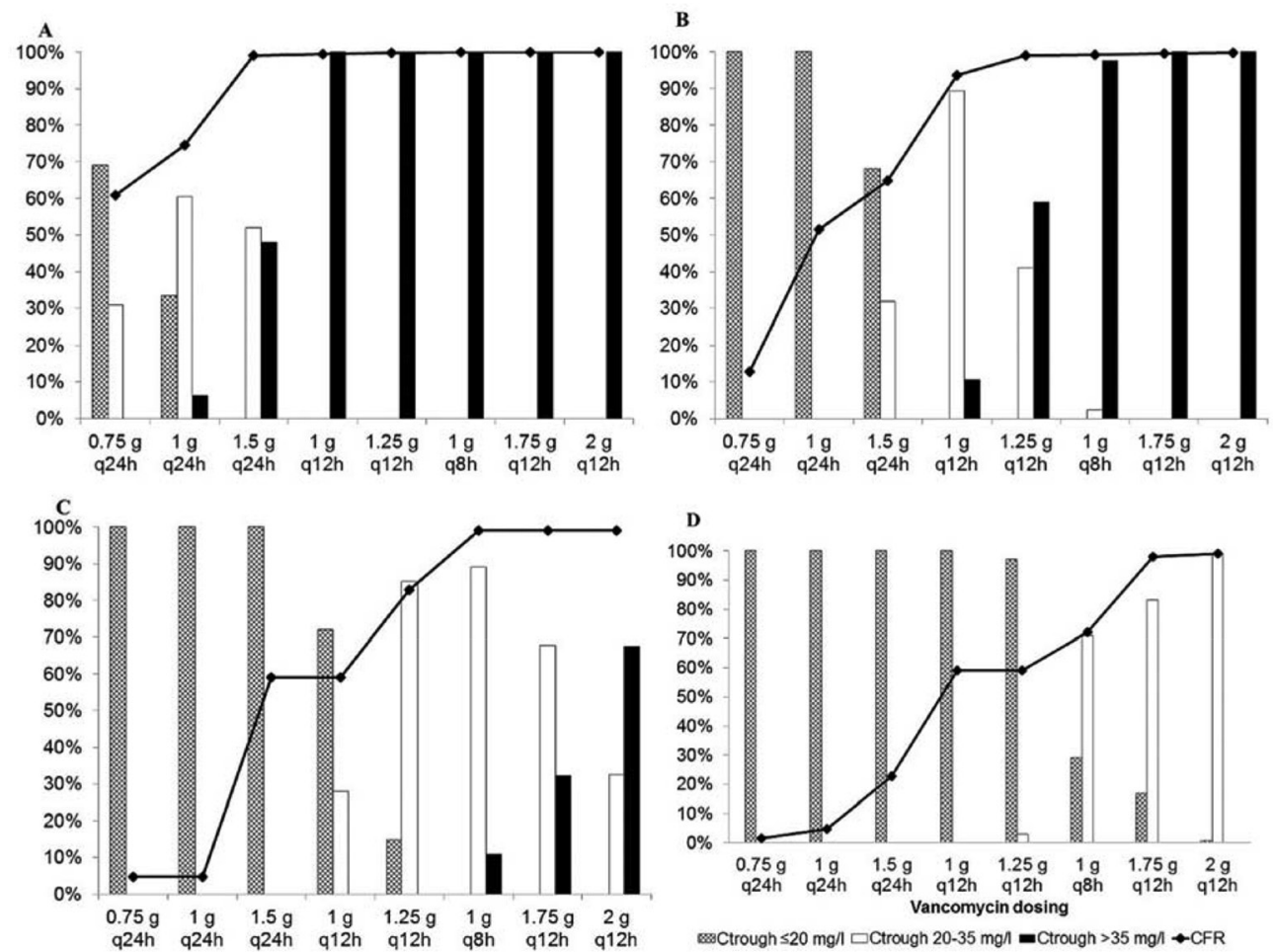

Figure 2. The cumulative fraction of response (CFR) achieving an area under the curve (AUC)/minimal inhibitory concentration (MIC) $>400$ and the percentage of trough concentration $\left(C_{\text {trough }}\right)$ of vancomycin at steady state for each dosing regimen in simulated patients with different renal functions. (A) $\mathrm{CL}_{c r}<40 \mathrm{~mL} / \mathrm{min}$, (B) $\mathrm{CL}_{c r} 40-60 \mathrm{~mL} / \mathrm{min},(\mathrm{C}) \mathrm{CL}_{c r}>60-80 \mathrm{~mL} / \mathrm{min}$, and (D) $\mathrm{CL}_{c r}>80 \mathrm{~mL} / \mathrm{min}$. q = quaque or every; I = liter 


\section{Conclusion}

Although vancomycin doses attained a CFR of $\geq 90 \%$ for effectively treating MRSA infection, these regimens may cause kidney injury. We recommend vancomycin doses of $0.75,1.5,1.5$, and $2 \mathrm{~g}$ daily for patients with a $\mathrm{CL}_{\mathrm{cr}}$ of $<40,40-60,>60-80$, and $>80 \mathrm{~mL} / \mathrm{min}$, respectively, should be given to patients infected with MRSA with a vancomycin MIC of $\leq 1 \mathrm{mg} / \mathrm{L}$ because these regimens will attain a PTA of $100 \%$ and the majority of patients will attain a $C_{\text {trough }}$ of $\leq 20 \mathrm{mg} / \mathrm{L}$.

Author contributions. WS and MP made substantial contributions to the conception and design of the study. KP and PS acquired the data, which was substantially analyzed and interpreted by KP, WS, MP, and JH. KP, WS, and MP drafted the manuscript. All authors critically revised the manuscript and take responsibility for the statements made in the article.

Acknowledgments. This study received funding from Research and Creative Fund, Faculty of Pharmacy, Silpakorn University, Nakhon Pathom, Thailand. We thank Pemika Panjakeaw and all collaborating staff in the Microbiology Laboratory, Chaoprayayomraj Hospital, Suphan Buri, Thailand who supported us by accumulating data for MRSA susceptibility to vancomycin.

Conflicts of interest statement. None of the authors have any conflict of interest to declare in relation to this article.

\section{References}

[1] Yamamoto M, Kuzuya T, Baba H, Yamada K, Nabeshima T. Population pharmacokinetic analysis of vancomycin in patients with gram-positive infections and the influence of infectious disease type. J Clin Pharm Ther. 2009; 34:473-83.

[2] Sánchez JL, Dominguez AR, Lane JR, Anderson PO, Capparelli EV, Cornejo-Bravo JM. Population pharmacokinetics of vancomycin in adult and geriatric patients: comparison of eleven approaches. Int J Clin Pharmacol Ther. 2010; 48:525-33.

[3] Revilla N, Martin-Suárez A, Pérez MP, González FM, Fernández de Gatta Mdel M. Vancomycin dosing assessment in intensive care unit patients based on a population pharmacokinetic/pharmacodynamic simulation. Br J Clin Pharmacol. 2010; 70:201-12.

[4] Blouin RA, Bauer LA, Miller DD, Record KE, Griffen WO Jr. Vancomycin pharmacokinetics in normal and morbidly obese subjects. Antimicrob Agents Chemother. 1982; 21:575-80.

[5] Matzke GR, McGory RW, Halstenson CE, Keane WF. Pharmacokinetics of vancomycin in patients with various degrees of renal function. Antimicrob Agents Chemother. 1984; 25:433-7.

[6] Purwonugroho TA, Chulavatnatol S, Preechagoon Y, Chindavijak B, Malathum K, Bunuparadah P. Population pharmacokinetics of vancomycin in Thai patients. ScientificWorldJournal. 2012; 2012:762649. doi: 10.1100/2012/762649.

[7] Canut A, Isla A, Betriu C, Gascón AR. Pharmacokineticpharmacodynamic evaluation of daptomycin, tigecycline, and linezolid versus vancomycin for the treatment of MRSA infections in four western European countries. Eur J Clin Microbiol Infect Dis. 2012; 31:2227-35.

[8] Housman ST, Sutherland CA, Nicolau DP. Pharmacodynamic profile of commonly utilised parenteral therapies against meticillin-susceptible and meticillin-resistant Staphylococcus aureus collected from US hospitals. Int J Antimicrob Agents. 2014; 44:235-41.

[9] Kuti JL, Kiffer CRV, Mendes CMF, Nicolau DP. Pharmacodynamic comparison of linezolid, teicoplanin and vancomycin against clinical isolates of Staphylococcus aureus and coagulase-negative staphylococci collected from hospitals in Brazil. Clin Microbiol Infect. 2008; 14:116-23.

[10] Mei Q, Ye Y, Zhu YL, Cheng J, Yang HF, Liu YY, et al. Use of Monte Carlo simulation to evaluate the development of vancomycin resistance in methicillin-resistant Staphylococcus aureus. Int J Antimicrob Agents. 2015; 45:652-56.

[11] Moise-Broder PA, Forrest A, Birmingham MC, Schentag JJ. Pharmacodynamics of vancomycin and other antimicrobials in patients with Staphylococcus aureus lower respiratory tract infections. Clin Pharmacokinet. 2004; 43:925-42.

[12] Bonate PL. A brief introduction to Monte Carlo simulation. Clin Pharmacokinet. 2001; 40:15-22.

[13] Roberts JA, Kirkpatrick CM, Lipman J. Monte Carlo simulations: maximizing antibiotic pharmacokinetic data to optimize clinical practice for critically ill patients. J Antimicrob Chemother. 2011; 66:227-31.

[14] Lodise TP, Patel N, Lomaestro BM, Rodvold KA, Drusano GL. Relationship between initial vancomycin concentration-time profile and nephrotoxicity among hospitalized patients. Clin Infect Dis. 2009; 49:507-14.

[15] Horey A, Mergenhagen KA, Mattappallil A. The relationship of nephrotoxicity to vancomycin trough serum concentrations in a veteran's population: a retrospective analysis. Ann Pharmacother. 2012; 46:1477-83.

[16] Rybak M, Lomaestro B, Rotschafer JC, Moellering R Jr., Craig W, Billeter $\mathrm{M}$, et al. Therapeutic monitoring of vancomycin in adult patients: a consensus review of the American Society of HealthSystem Pharmacists, the Infectious Diseases Society of America, and the Society of Infectious Diseases Pharmacists. Am J Health Syst Pharm. 2009; 66:82-98.

[17] Rybak MJ. The pharmacokinetic and pharmacodynamic properties of vancomycin. Clin Infect Dis. 2006; 42 Suppl 1:S35-9.

[18] Lodise TP, Graves J, Evans A, Graffunder E, Helmecke M, Lomaestro BM, et al. Relationship between vancomycin MIC and failure among patients with methicillin-resistant Staphylococcus aureus bacteremia treated with vancomycin. Antimicrob Agents Chemother. 2008; 52:3315-20. 
[19] Elyasi S, Khalili H, Dashti-Khavidaki S, Mohammadpour A. Vancomycin-induced nephrotoxicity: mechanism, incidence, risk factors and special populations. A literature review. Eur J Clin Pharmacol. 2012; 68:1243-55.

[20] Gould IM, Cauda R, Esposito S, Gudiol F, Mazzei T, Garau J. Management of serious methicillin-resistant Staphylococcus aureus infections: what are the limits? Int J Antimicrob Agents. 2011; 37:202-9.
[21] Lodise TP, McKinnon PS, Swiderski L, Rybak MJ. Outcomes analysis of delayed antibiotic treatment for hospital-acquired Staphylococcus aureus bacteremia. Clin Infect Dis. 2003; 36:1418-23.

[22] Tsuji BT, Rybak MJ, Lau KL, Sakoulas G. Evaluation of accessory gene regulator $(a g r)$ group and function in the proclivity towards vancomycin intermediate resistance in Staphylococcus aureus. Antimicrob Agents Chemother. 2007; 51:1089-91. 
